\title{
A Comparative and Comprehensive Analysis of Smart Contract Enabled Blockchain Applications
}

\author{
Vishalkumar Langaliya ${ }^{1}$ \\ Research Scholar, Department of Computer Application, Marwadi University, Rajkot, Gujarat 360003. India. \\ https://orcid.org/0000-0001-9581-547X, \\ vishal.langaliya@gmail.com \\ Jaypalsinh A. Gohil ${ }^{2}$ \\ Assistant Professor, Department of Computer Application, Marwadi University, Rajkot, Gujarat 360003. India. \\ jaypalsinh.gohil@marwadieducation.edu.in \\ https://orcid.org/0000-0003-0925-6646
}

\begin{abstract}
Blockchain is a disruptive innovation that is already reshaping corporate, social, and political connections, as well as any other form of value exchange. Again, this isn't simply a shift; it's a fast-moving phenomenon that has already begun. Top financial institutions and a large number of businesses have begun to investigate blockchain in order to cut transaction costs, speed up transaction times, reduce fraud risk, and eliminate the need for middlemen or intermediate services. Blockchain is believed to be the component that completes the Internet puzzle and makes it more open, more accessible, and more reliable. In this article, we first introduced the blockchain technology and smart contracts and their merits and demerits. Second, we present a comparative and comprehensive analysis of smart contract-enabled blockchain applications. Toward the end, we discussed the future development trends of smart contract enabled blockchain applications. This document is intended to serve as a guide and resource for future research initiatives.
\end{abstract}

Keywords- Blockchain, Smart contracts, Blockchain Applications, Comparative Analysis.

\section{INTRODUCTION}

Blockchain is model for delivering the information because it provides immediate, shareable, and completely transparent data stored on an immutable ledger that can only be read by permissioned network members. A blockchain network can track orders, payments, accounts, production, and much more. Because affiliates share a single view of the fact, you can see all the facts of a transaction from beginning to end, giving you more confidence as well as new efficiencies and opportunities.

Blockchain $^{1}$ is a decentralised, immutable database that simplifies the recording of transactions and asset tracking in a corporate network. A tangible item (such as a house, car, cash, or land) can also be an intangible asset (intellectual property, patents, copyrights, branding). Almost everything of value may be recorded and traded on the blockchain network, which reduces risk and lowers costs for all parties involved.

Bitcoin $^{2}$ is a peer-to-peer payment system that eliminates the need for trusted third parties. Bitcoin is a decentralized cryptocurrency that is not restricted to any nation and is a global currency. It is decentralized in every aspecttechnical, logical, as well as political [1].

Ethereum $^{3}$ is a piece of software that runs on a network of computers and ensures that data and small computer programmes known as smart contracts are duplicated and processed across the entire network without the need for a central controller.

1. Blockchain. https://www.ibm.com/in-en/topics/what-is-blockchain

2. Bitcoin. https://bitcoin.org/en/

3. Ethereum. https://ethereum.org/ 
It builds on the Bitcoin blockchain principle of validating, storing, and replicating transaction data across multiple computers all over the world (thus the term "distributed ledger"). Ethereum goes a step farther by running computer code on numerous computers around the globe in the same way. [2].

The word was invented in the 1990s by cryptographer Nick Szabo, who defined it as "a set of promises, expressed in digital form, including mechanisms within which the parties fulfil on the other promises." Smart contracts ${ }^{4}$ have grown since then, particularly since the introduction of decentralised blockchain platforms with the birth of Bitcoin in 2009[3]. The majority of smart contracts are written in a high-level language like Solidity. However, in order to run, they must be assembled to the EVM's low-level bytecode. They are installed on the Ethereum platform using a specific contract creation transaction, which is identifiable as such by being submitted to the special contract creation address, after they have been compiled.

Hyperledger $^{5}$ is an open source project that aims to develop blockchain technology across industries. It's a worldwide cooperation that includes leaders in banking, finance, IoT, manufacturing, supply chains, and technology. Hyperledger is hosted by the Linux Foundation, a non-profit organisation dedicated to facilitating mass creativity through open source. The Linux Foundation also facilitates collaboration and sharing of ideas, infrastructure, and code across a global developer community.

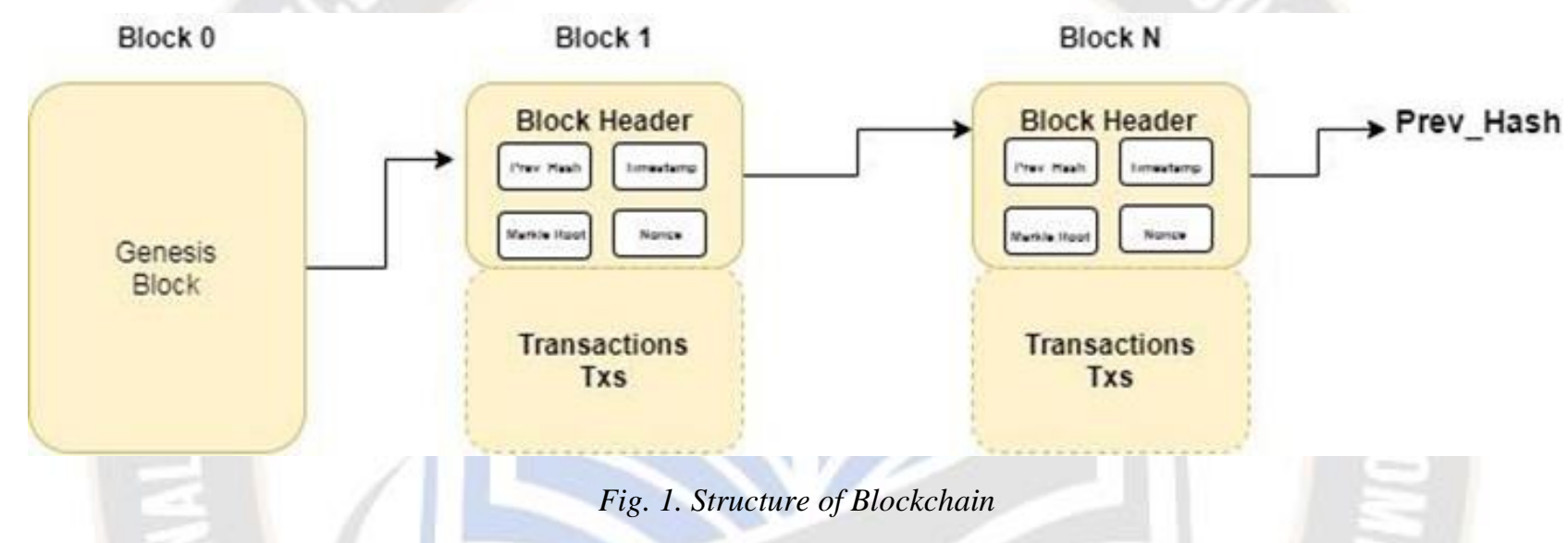

\section{LITERATURE SURVEY}

Fahim Ullah et al [2021], The authors employed the systematic review method to examine and analyse material published between 2000 and 2020. The literature focuses on the application of blockchain smart contracts in smart real estate and presents a conceptual framework for their implementation in smart cities that govern real estate negotiations [4]. Ten major characteristics of blockchain smart contracts are addressed in the article, which are organised into six tiers for smart real estate adoption. To demonstrate the development of a smart contract that may be utilised for blockchain smart contracts in real estate, the decentralised application and its interactions with the Ethereum Virtual Machine (EVM) are described. Real estate owners and users as smart contract parties benefit from a sophisticated design and engagement mechanism. A stepby-step approach for establishing and ending smart contracts is described, as well as a list of functions for initiating, generating, changing, or terminating smart contracts. The suggested framework is a contractual process that is more immersive, user-friendly, and visualised. 
Adarsh kumar et al [2020], The authors propose a smart healthcare system with a blockchain data network and healthcare 4.0 processes, which include industry 4.0 processes such as the internet of things (IoT), industrial IoT (IIoT), cognitive computing, artificial intelligence, cloud computing, fog computing, edge computing to provide transparency, easy and faster accessibility, security, efficiency[5]. The Ethereum network, as well as associated programming languages, tools, and techniques such as solidity, web3.js, Athena, and others, are used to construct the smart healthcare system. The learning created a comprehensive and comparative survey of cutting-edge blockchain-based smart healthcare systems. A simulationoptimization approach using JaamSim simulator is proposed to improve the performance of the overall system and subsystems. The proposed approach is tested, verified and validated through simulation and implementation.

Mayank Raikwar et al [2018], An experimental prototype was built on Hyperledger fabric, an open source permissioned blockchain design platform, by the authors [6]. They discussed the most important design needs and design propositions, as well as how to encode various insurance procedures into smart contracts. Extensive experiments were conducted to analyse performance of framework and security of the proposed design and transactions based on a blockchain-enabled platform.

Hoai Luan Pham et al [2018], Patients, healthcare providers (such as hospitals), and healthcare professionals (doctors) formed a remote healthcare system. Sensors were used to control the health of patients, and this information was automatically put into the blockchain [7]. In addition, they presented a processing technique for efficiently and sparingly storing medical device information based on the patient's health status. In specific, they filtered sensor data before deciding whether or not to send it to blockchain. As a result, they will be able to minimise the size of the blockchain and save a significant quantity of coins for transaction efficiency. However, abnormal data from sensors would be promptly written to blockchain, triggering an emergency call to a doctor and hospital for prompt treatment. They tested the proposed smart contract on Ethereum's TESTRPC test environment and built the system in a real-world setting with real devices. At a small scale, this system functioned successfully.

Toqeer Ali et al [2020], Authors proposed a Transparent and Reliable Property Registration System on Permissioned Blockchain which provide the solution of the problem within this mechanism is that there is no transparency regarding the integrity of data about a property. i.e. the person-in-charge can manipulate the information within the database and provide misinformation to the involved stakeholders as being a manual process [8]. They took Saudi Arabia as a use-case and designed the system accordingly to transform the property registration on blockchain for the country. This study delivers a solution for governing transparency and satiates in the provision of a trusted property registration system over the Blockchain for the kingdom of Saudi Arabia. The infrastructure offers many features to the stakeholders related to the purchasing and retailing of property. The transparency, integrity of the record, and trust factor is ensured via a tamper-proof ledger

Olawande Daramola et al [2020], demonstrates how the Architecture Trade-off Analysis Method (ATAM) may help stakeholders in national elections assess the risks, opportunities, and challenges that a blockchain e-voting system for national elections could bring. Using a study context of South Africa as a case study, a proposed blockchain e-voting architecture was used to assist election stakeholders in reasoning on the concept of blockchain evoting in order to educate them on the possible hazards, security concerns, important requirements qualities, and flaws related with deploying blockchain e-voting for national elections [9]. According to the report, blockchain evoting can prevent security breaches, internal vote manipulation, and boost transparency.

Valentina Gatteschi et al [2018], The author of the paper uses blockchain to illustrate the process of decision- making by actors in the insurance system, analysing its benefits and drawbacks, and discussing many use examples from the insurance industry that may easily be expanded to other areas [10].

Sujit Biswas et al [2020], they first analyse and explain how business blockchain can be effectively used in healthcare, followed by the unique requirements of a healthcare system. In the latter parts of this article, they discuss the migration challenges and possible solution, the trade-off between unified and multi-chain environments, consensus algorithms for healthcare, users \& access privileges, smart contracts, and e-healthcare specific industry regulations [11]. The goal of this paper was to show how difficult it is to establish a blockchain solution for e-healthcare systems and to explore for potential alternatives.

Friorik P. Hjalmarsson et al [2018], They propose a unique electronic voting system based on blockchain in this research paper, which tackles some of the shortcomings of existing systems and examines some of the most wellknown blockchain frameworks for the aim of building a blockchain-based e-voting system [12]. They unveiled a blockchain-based electronic voting system that makes use of 
smart contracts to ensure a secure and cost-effective election while also protecting voters' privacy.

Tanesh Kumar et al [2018], Exploring the possible applications of blockchain technology in present healthcare systems, as well as the most critical needs for such systems, such as trustless and transparent healthcare systems [13]. In addition, this report also outlines the hurdles and roadblocks that must be overwhelmed before blockchain technology can be successfully implemented in healthcare systems. they also introduce the smart contract for blockchain-based healthcare systems, which is critical for setting pre-defined agreements among various players.

Ioannis Karamitsos et al [2018], The goal of this article is to present Blockchain and smart contracts in the context of real estate. A full smart contract design is described, followed by an examination of a use case for renting residential and commercial premises [14]. They present a smart contract design technique that allows for the development of various use cases using Blockchain technology. A full description of state finite functions and processes is provided for a specific use case that makes significant contributions to the real estate domain.

Rohan Bennett et al [2021], The authors show how comparative analysis may be done utilising a variety of frameworks, such as business requirements adherence, technology eagerness and maturity assessment, and strategic grid analysis. The findings suggest that the hybrid strategy allows for compliance with land dealing business criteria, and that proofs-of-concept are an important phase in the development process [15]. Finally, a maturity model for the use of blockchain and smart contracts in land transactions is offered.

Vinay Thakura et al [2019], It highlights concerns such as nominal transparency, accountability, incoherent data sets with several government departments pertaining to the same piece of land, and delays in the current Land Records management procedure, as well as how to fix these issues utilising Blockchain Technology [16]. The authors also demonstrate a system design for the deployment of a Land Titling system utilising Blockchain Technology, so that land titles are tamper-proof and give legitimate and conclusive rights on ownership. The research report recommends utilising Blockchain's inherent benefits, with a focus on smart contracts.

Each transaction, whether it is a property sale, an inheritance, a court order, or a land acquisition, will be captured and permanently recorded by the system. This means you get near-real-time updated records with accurate traceability and visibility into the state of your property records. 


\section{COMPARATIVE AND COMPREHENSIVE REVIEW ANALYSIS BASED ON SELECTIVE CRITERIA.}

\begin{tabular}{|c|c|c|c|c|c|c|c|c|}
\hline Authors & $\begin{array}{c}\text { Year of } \\
\text { Publica } \\
\text { tion }\end{array}$ & $\begin{array}{c}\text { Blockchai } \\
\text { n } \\
\text { Applicati } \\
\text { on } \\
\text { Domain }\end{array}$ & $\begin{array}{c}\text { Problem } \\
\text { Statement }\end{array}$ & $\begin{array}{c}\text { Researc } \\
\text { h } \\
\text { Method }\end{array}$ & Solution & $\begin{array}{l}\text { Whet } \\
\text { her } \\
\text { Soluti } \\
\text { on is } \\
\text { tested } \\
\text { ? }\end{array}$ & $\begin{array}{l}\text { Deployme } \\
\text { nt or } \\
\text { Implement } \\
\text { ation }\end{array}$ & $\begin{array}{c}\text { Future } \\
\text { scope }\end{array}$ \\
\hline$x+\frac{2}{2}=$ & 2021 & $\begin{array}{l}\text { Real } \\
\text { Estate } \\
\text { Deals in } \\
\text { smart } \\
\text { cities }\end{array}$ & $\begin{array}{l}\text { blockchain } \\
\text { smart } \\
\text { contract } \\
\text { adoption } \\
\text { to manage } \\
\text { real estate } \\
\text { deals in } \\
\text { smart } \\
\text { cities }\end{array}$ & $\begin{array}{l}\text { conceptu } \\
\text { al } \\
\text { framewo } \\
\text { rk }\end{array}$ & $\begin{array}{l}\text { propose a } \\
\text { new smart } \\
\text { contract } \\
\text { architectur } \\
\text { e for real } \\
\text { estate } \\
\text { transaction } \\
\text { s }\end{array}$ & Yes & Yes & $\begin{array}{l}\text { To } \\
\text { illustrate } \\
\text { the smart } \\
\text { contract } \\
\text { process in } \\
\text { smart real } \\
\text { estate, a } \\
\text { practical } \\
\text { framewor } \\
\mathrm{k} \text { in the } \\
\text { form of a } \\
\text { sophisticat } \\
\text { ed website } \\
\text { or app can } \\
\text { be } \\
\text { establishe } \\
\text { d. }\end{array}$ \\
\hline $\begin{array}{l}\text { Adarsh } \\
\text { Kumar } \\
\text { Rajalaksh } \\
\text { mi } \\
\text { Krishnam } \\
\text { urthi, } \\
\text { Anand } \\
\text { Nayyar, } \\
\text { Kriti } \\
\text { Sharma, } \\
\text { Vinay } \\
\text { Grover } \\
\text { and Eklas } \\
\text { Hossain }\end{array}$ & 2020 & $\begin{array}{l}\text { Novel } \\
\text { Smart } \\
\text { Healthcar } \\
\text { e } 4.0 \\
\text { Processes }\end{array}$ & $\begin{array}{l}\text { Create a } \\
\text { smart } \\
\text { healthcare } \\
\text { system } \\
\text { using } \\
\text { Blockchai } \\
\text { n } 3.0 \text { and } \\
\text { Healthcare } \\
4.0 \\
\text { connectivit } \\
\text { y and } \\
\text { interopera } \\
\text { bility. }\end{array}$ & $\begin{array}{l}\text { conceptu } \\
\text { al } \\
\text { framewo } \\
\text { rk }\end{array}$ & $\begin{array}{l}\text { Integration } \\
\text { and } \\
\text { interopera } \\
\text { bility of } \\
\text { Blockchai } \\
\text { n } 3.0 \text { and } \\
\text { Healthcare } \\
4.0 \text { to } \\
\text { create a } \\
\text { smart } \\
\text { healthcare } \\
\text { system }\end{array}$ & Yes & $\begin{array}{l}\text { Implement } \\
\text { ed on } \\
\text { Ethereum } \\
\text { using tools } \\
\text { solidity, } \\
\text { web3.js, } \\
\text { Athena, } \\
\text { etc. }\end{array}$ & $\begin{array}{l}\text { The } \\
\text { proposed } \\
\text { work will } \\
\text { be } \\
\text { expanded } \\
\text { to include } \\
\text { implement } \\
\text { ation } \\
\text { across } \\
\text { many } \\
\text { blockchai } \\
\text { n } \\
\text { networks } \\
\text { using } \\
\text { various } \\
\text { tools and } \\
\text { methodolo } \\
\text { gies. }\end{array}$ \\
\hline $\begin{array}{l}\text { Mayank } \\
\text { Raikwar } \\
\text { Subhra } \\
\text { Mazumdar } \\
\text {, Sushmita } \\
\text { Ruj, } \\
\text { Sourav } \\
\text { Sen } \\
\text { Gupta, }\end{array}$ & 2018 & $\begin{array}{l}\text { Insurance } \\
\text { Processes }\end{array}$ & $\begin{array}{l}\text { Design an } \\
\text { experimen } \\
\text { tal } \\
\text { prototype } \\
\text { on } \\
\text { Hyperledg } \\
\text { er fabric, } \\
\text { an open } \\
\text { source } \\
\end{array}$ & $\begin{array}{l}\text { Design } \\
\text { Experim } \\
\text { ental } \\
\text { Prototyp } \\
\text { e }\end{array}$ & $\begin{array}{l}\text { Prepare a } \\
\text { model for } \\
\text { a cost- } \\
\text { effective } \\
\text { way to } \\
\text { processing } \\
\text { insurance- } \\
\text { related } \\
\text { transaction }\end{array}$ & Yes & No & $\begin{array}{l}\text { Each } \\
\text { smart } \\
\text { contract in } \\
\text { the model } \\
\text { has its } \\
\text { own } \\
\text { collection } \\
\text { of } \\
\text { endorsing }\end{array}$ \\
\hline
\end{tabular}




\begin{tabular}{|c|c|c|c|c|c|c|c|c|}
\hline $\begin{array}{l}\text { Anupam } \\
\text { Chattopad } \\
\text { hyay, and } \\
\text { Kwok- } \\
\text { Yan Lam }\end{array}$ & & & $\begin{array}{l}\text { permission } \\
\text { ed } \\
\text { blockchain } \\
\text { design } \\
\text { framework } \\
\text {. }\end{array}$ & & $\begin{array}{l}\text { s on a } \\
\text { blockchain } \\
\text { network. }\end{array}$ & & & $\begin{array}{l}\text { peers, } \\
\text { which } \\
\text { may be } \\
\text { extended } \\
\text { to the } \\
\text { transactio } \\
\text { n level to } \\
\text { allow for a } \\
\text { separate } \\
\text { group of } \\
\text { endorsing } \\
\text { peers for } \\
\text { each } \\
\text { transactio } \\
\text { n. }\end{array}$ \\
\hline $\begin{array}{l}\text { Hoai Luan } \\
\text { Pham, Thi } \\
\text { Hong } \\
\text { Tran, } \\
\text { Yasuhiko } \\
\text { Nakashim } \\
\text { a }\end{array}$ & 2018 & $\begin{array}{l}\text { Secure } \\
\text { Remote } \\
\text { Healthcar } \\
\text { e System } \\
\text { for } \\
\text { Hospital }\end{array}$ & $\begin{array}{l}\text { Proposed } \\
\text { remote } \\
\text { healthcare } \\
\text { system } \\
\text { using } \\
\text { blockchain } \\
\text { based on } \\
\text { the } \\
\text { Ethereum } \\
\text { protocol }\end{array}$ & $\begin{array}{l}\text { Design } \\
\text { of } \\
\text { Experim } \\
\text { ental } \\
\text { processi } \\
\text { ng } \\
\text { mechani } \\
\text { sm }\end{array}$ & $\begin{array}{l}\text { Prepared } \\
\text { and tested } \\
\text { a Remote } \\
\text { Healthcare } \\
\text { System } \\
\text { based on } \\
\text { Smart } \\
\text { Contract } \\
\text { on } \\
\text { blockchain } \\
\text { technolog } \\
\text { y }\end{array}$ & Yes & $\begin{array}{l}\text { verified the } \\
\text { proposed } \\
\text { smart } \\
\text { contract on } \\
\text { Ethereum } \\
\text { test } \\
\text { environme } \\
\text { nt called } \\
\text { TESTRPC } \\
\text { and } \\
\text { implemente } \\
\text { d the } \\
\text { system on } \\
\text { an } \\
\text { experiment } \\
\text { al } \\
\text { environme } \\
\text { nt with real } \\
\text { devices. }\end{array}$ & $\begin{array}{l}\text { For the } \\
\text { suggested } \\
\text { remote } \\
\text { healthcare } \\
\text { system, } \\
\text { decentralis } \\
\text { ed storage } \\
\text { can be } \\
\text { developed. } \\
\\
\\
\end{array}$ \\
\hline $\begin{array}{l}\text { Toqeer } \\
\text { Ali, } \\
\text { Adnan } \\
\text { Nadeem, } \\
\text { Ali } \\
\text { Alzahrani, } \\
\text { Salman } \\
\text { Jan }\end{array}$ & 2020 & $\begin{array}{l}\text { Property } \\
\text { Registrati } \\
\text { on System }\end{array}$ & $\begin{array}{l}\text { Discover a } \\
\text { Permission } \\
\text { ed } \\
\text { Blockchai } \\
\text { n-based } \\
\text { Transpare } \\
\text { nt and } \\
\text { Trusted } \\
\text { Property } \\
\text { Registratio } \\
\text { n System. }\end{array}$ & $\begin{array}{l}\text { Use } \\
\text { case- } \\
\text { based } \\
\text { study } \\
\text { and } \\
\text { design } \\
\text { framewo } \\
\text { rk. }\end{array}$ & $\begin{array}{l}\text { For the } \\
\text { Kingdom } \\
\text { of Saudi } \\
\text { Arabia, } \\
\text { this } \\
\text { solution } \\
\text { controls } \\
\text { transparen } \\
\text { cy and } \\
\text { satisfies in } \\
\text { the } \\
\text { provision } \\
\text { of a } \\
\text { trusted } \\
\text { property } \\
\text { registratio } \\
\mathrm{n} \text { system } \\
\text { on the } \\
\text { Blockchai } \\
\text { n. The } \\
\text { infrastruct } \\
\text { ure } \\
\text { provides }\end{array}$ & No & No & $\begin{array}{l}\text { After } \\
\text { testing, } \\
\text { the } \\
\text { recommen } \\
\text { ded } \\
\text { framewor } \\
k \text { and } \\
\text { system } \\
\text { design } \\
\text { will be } \\
\text { implement } \\
\text { ed and } \\
\text { improved } \\
\text { utilising } \\
\text { the } \\
\text { appropriat } \\
\text { e } \\
\text { platform. }\end{array}$ \\
\hline
\end{tabular}




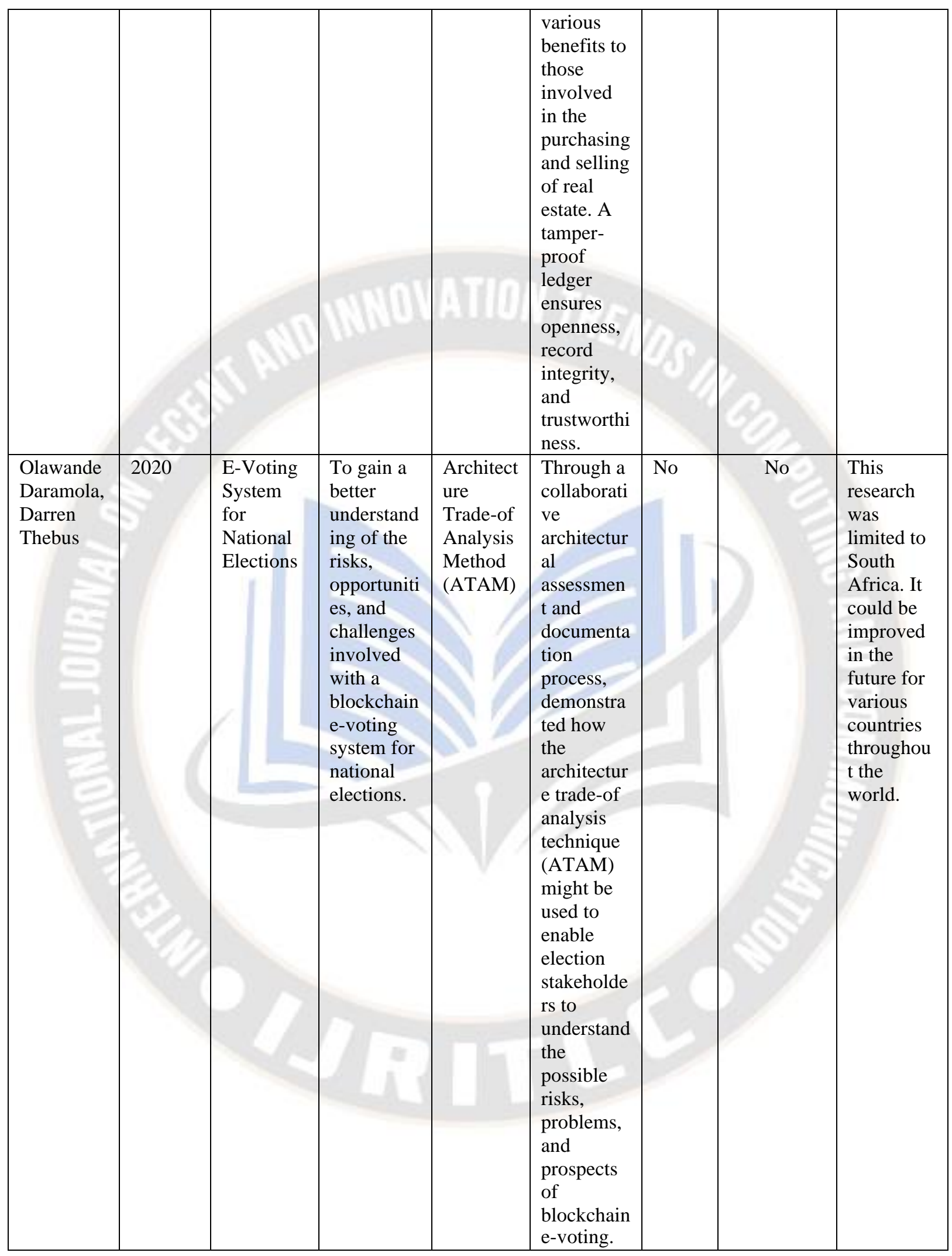




\begin{tabular}{|c|c|c|c|c|c|c|c|c|}
\hline $\begin{array}{l}\text { Valentina } \\
\text { Gatteschi, } \\
\text { Fabrizio } \\
\text { Lamberti, } \\
\text { Claudio } \\
\text { Demartini } \\
\text { Chiara } \\
\text { Pranteda } \\
\text { and Víctor } \\
\text { Santamarí } \\
\text { a }\end{array}$ & 2018 & $\begin{array}{l}\text { Insurance } \\
\text { Processes }\end{array}$ & $\begin{array}{l}\text { To provide } \\
\text { assistance } \\
\text { to those } \\
\text { involved } \\
\text { in the } \\
\text { decision- } \\
\text { making } \\
\text { process, as } \\
\text { well as to } \\
\text { discuss } \\
\text { many use } \\
\text { examples } \\
\text { from the } \\
\text { insurance } \\
\text { industry } \\
\text { that might } \\
\text { easily be } \\
\text { applied to } \\
\text { other } \\
\text { domains. }\end{array}$ & $\begin{array}{l}\text { SWOT } \\
\text { Analysis }\end{array}$ & $\begin{array}{l}\text { Outline } \\
\text { the } \\
\text { benefits } \\
\text { and } \\
\text { drawbacks } \\
\text {, as well as } \\
\text { explore } \\
\text { specific } \\
\text { applicatio } \\
\text { n instances } \\
\text { from the } \\
\text { insurance } \\
\text { industr }\end{array}$ & No & No & $\begin{array}{c}\text { Based on } \\
\text { the results } \\
\text { of the } \\
\text { SWOT } \\
\text { analysis, } \\
\text { blockchai } \\
n \\
\text { technolog } \\
\text { y might be } \\
\text { easily } \\
\text { extended } \\
\text { to } \\
\text { different } \\
\text { industries. }\end{array}$ \\
\hline $\begin{array}{l}\text { Sujit } \\
\text { Biswas, } \\
\text { Kashif } \\
\text { Sharif, } \\
\text { Fan Li, } \\
\text { Saraju P. } \\
\text { Mohanty }\end{array}$ & 2020 & $\begin{array}{l}\text { E- } \\
\text { Healthcar } \\
\text { e } \\
\text { Systems. }\end{array}$ & $\begin{array}{l}\text { To gain a } \\
\text { better } \\
\text { understand } \\
\text { ing of how } \\
\text { difficult it } \\
\text { is to } \\
\text { establish a } \\
\text { blockchain } \\
\text { solution } \\
\text { for e- } \\
\text { healthcare } \\
\text { systems } \\
\text { and to } \\
\text { seek for } \\
\text { potential } \\
\text { solutions. }\end{array}$ & $\begin{array}{l}\text { Literatur } \\
\text { e Survey }\end{array}$ & $\begin{array}{l}\text { examine } \\
\text { and } \\
\text { explain } \\
\text { how } \\
\text { business } \\
\text { blockchain } \\
\text { can be } \\
\text { used } \\
\text { effectively } \\
\text { in } \\
\text { healthcare, } \\
\text { as well as } \\
\text { the special } \\
\text { needs of } \\
\text { the } \\
\text { healthcare } \\
\text { sector. }\end{array}$ & No & No & $\begin{array}{l}\text { The } \\
\text { findings of } \\
\text { the study } \\
\text { can be } \\
\text { applied to } \\
\text { the } \\
\text { developm } \\
\text { ent of a } \\
\text { blockchai } \\
\text { n } \\
\text { applicatio } \\
\text { n. }\end{array}$ \\
\hline $\begin{array}{l}\text { Frorik P. } \\
\text { Hjalmarss } \\
\text { on, } \\
\text { Gunnlaug } \\
\text { ur K. } \\
\text { Hreioarsso } \\
\text { n, } \\
\text { Mohamma } \\
\text { d } \\
\text { Hamdaqa, } \\
\text { Gisli } \\
\text { Hjalmtyss } \\
\text { on }\end{array}$ & 2018 & $\begin{array}{l}\text { E-Voting } \\
\text { System }\end{array}$ & $\begin{array}{l}\text { developing } \\
\text { an e- } \\
\text { voting } \\
\text { system } \\
\text { based on } \\
\text { the } \\
\text { blockchain }\end{array}$ & $\begin{array}{l}\text { Design } \\
\text { of } \\
\text { experime } \\
\text { ntal } \\
\text { framewo } \\
\text { rk }\end{array}$ & $\begin{array}{l}\text { Proposed a } \\
\text { blockchain } \\
\text {-based } \\
\text { electronic } \\
\text { voting } \\
\text { system } \\
\text { that uses } \\
\text { smart } \\
\text { contracts } \\
\text { to ensure } \\
\text { that } \\
\text { elections } \\
\text { are secure } \\
\text { and cost- } \\
\text { effective } \\
\text { while } \\
\text { maintainin } \\
\text { g voter } \\
\text { anonymity } \\
\text {. }\end{array}$ & Yes & Yes & $\begin{array}{l}\text { Additional } \\
\text { measures } \\
\text { would be } \\
\text { required } \\
\text { for } \\
\text { countries } \\
\text { of greater } \\
\text { size to } \\
\text { accommo } \\
\text { date } \\
\text { higher } \\
\text { transactio } \\
\text { n volume } \\
\text { per } \\
\text { second. }\end{array}$ \\
\hline
\end{tabular}




\begin{tabular}{|c|c|c|c|c|c|c|c|c|}
\hline $\begin{array}{l}\text { Tanesh } \\
\text { Kumar, } \\
\text { Vidhya } \\
\text { Ramani, } \\
\text { Ijaz } \\
\text { Ahmad, } \\
\text { An } \\
\text { Braeken, } \\
\text { Erkki } \\
\text { Harjula, } \\
\text { Mika } \\
\text { Ylianttila }\end{array}$ & 2018 & $\begin{array}{l}\text { healthcare } \\
\text { systems }\end{array}$ & $\begin{array}{l}\text { To outline } \\
\text { the issues } \\
\text { and } \\
\text { roadblocks } \\
\text { that must } \\
\text { be } \\
\text { overcome } \\
\text { before } \\
\text { blockchain } \\
\text { technology } \\
\text { can be } \\
\text { successfull } \\
\text { y } \\
\text { implement } \\
\text { ed in } \\
\text { healthcare } \\
\text { systems. }\end{array}$ & $\begin{array}{l}\text { Literatur } \\
\text { e survey }\end{array}$ & $\begin{array}{l}\text { present the } \\
\text { smart } \\
\text { contract } \\
\text { for } \\
\text { blockchain } \\
\text {-based } \\
\text { healthcare } \\
\text { systems, } \\
\text { which is } \\
\text { critical for } \\
\text { setting } \\
\text { pre- } \\
\text { defined } \\
\text { agreement } \\
\text { s among } \\
\text { the } \\
\text { numerous } \\
\text { stakeholde } \\
\text { rs } \\
\text { involved. }\end{array}$ & No & No & $\begin{array}{l}\text { Facts may } \\
\text { be put into } \\
\text { practise } \\
\text { with the } \\
\text { right tools. }\end{array}$ \\
\hline $\begin{array}{l}\text { Ioannis } \\
\text { Karamitso } \\
\text { s, Maria } \\
\text { Papadaki, } \\
\text { Nedaa } \\
\text { Baker Al } \\
\text { Barghuthi } \\
\end{array}$ & 2018 & $\begin{array}{l}\text { Real } \\
\text { Estate } \\
\text { System }\end{array}$ & $\begin{array}{l}\text { offer a } \\
\text { smart } \\
\text { contract } \\
\text { design } \\
\text { process } \\
\text { that allows } \\
\text { for the } \\
\text { developme } \\
\text { nt of } \\
\text { various } \\
\text { use cases } \\
\text { using } \\
\text { Blockchai } \\
\text { n } \\
\text { technology } \\
\text {. }\end{array}$ & $\begin{array}{l}\text { Concept } \\
\text { ual } \\
\text { framewo } \\
\text { rk }\end{array}$ & $\begin{array}{l}\text { A full } \\
\text { descriptio } \\
\mathrm{n} \text { of state } \\
\text { finite } \\
\text { functions } \\
\text { and } \\
\text { processes } \\
\text { is } \\
\text { provided } \\
\text { for a } \\
\text { specific } \\
\text { use case } \\
\text { that makes } \\
\text { significant } \\
\text { contributio } \\
\text { ns to the } \\
\text { real estate } \\
\text { domain. }\end{array}$ & Yes & Yes & $\begin{array}{l}\text { must } \\
\text { evaluate } \\
\text { the impact } \\
\text { of various } \\
\text { platforms } \\
\text { such as } \\
\text { Hyperledg } \\
\text { er Fabric } \\
\\
- \\
\end{array}$ \\
\hline $\begin{array}{l}\text { Rohan } \\
\text { Bennett, } \\
\text { Todd } \\
\text { Miller, } \\
\text { Mark } \\
\text { Pickering, } \\
\text { Al-Karim } \\
\text { Kara }\end{array}$ & 2021 & $\begin{array}{l}\text { Land } \\
\text { Administr } \\
\text { ation }\end{array}$ & $\begin{array}{l}\text { Proposed a } \\
\text { Hybrid } \\
\text { Approache } \\
\text { s for Smart } \\
\text { Contracts } \\
\text { in Land } \\
\text { Administr } \\
\text { ation }\end{array}$ & $\begin{array}{l}\text { Compara } \\
\text { tive } \\
\text { analysis }\end{array}$ & $\begin{array}{l}\text { A maturity } \\
\text { model for } \\
\text { the use of } \\
\text { blockchain } \\
\text { and smart } \\
\text { contracts } \\
\text { in land } \\
\text { transaction } \\
\text { s. }\end{array}$ & Yes & Yes & $\begin{array}{l}\text { Institution } \\
\text { al trust, } \\
\text { legal, and } \\
\text { policy } \\
\text { challenges } \\
\text { are some } \\
\text { of the } \\
\text { major } \\
\text { issues that } \\
\text { can be } \\
\text { addressed. }\end{array}$ \\
\hline
\end{tabular}




\begin{tabular}{|c|c|c|c|c|c|c|c|c|}
\hline $\begin{array}{l}\text { Vinay } \\
\text { Thakura,, } \\
\text { M.N. } \\
\text { Dojab, } \\
\text { Yogesh K. } \\
\text { Dwivedic, } \\
\text { Tanvir } \\
\text { Ahmadd, } \\
\text { Ganesh } \\
\text { Khadanga } \\
\text { e }\end{array}$ & 2015 & $\begin{array}{l}\text { Land } \\
\text { Titling } \\
\text { System }\end{array}$ & $\begin{array}{l}\text { Land } \\
\text { records on } \\
\text { Blockchai } \\
\mathrm{n} \text { for } \\
\text { implement } \\
\text { ation of } \\
\text { Land } \\
\text { Titling in } \\
\text { India }\end{array}$ & $\begin{array}{l}\text { Concept } \\
\text { ual } \\
\text { framewo } \\
\text { rk and } \\
\text { design of } \\
\text { system }\end{array}$ & $\begin{array}{l}\text { Illustrates } \\
\text { a system } \\
\text { design for } \\
\text { implement } \\
\text { ing a Land } \\
\text { Titling } \\
\text { system in } \\
\text { the } \\
\text { country } \\
\text { utilising } \\
\text { Blockchai } \\
n \\
\text { Technolog } \\
\text { y, so that } \\
\text { land titles } \\
\text { are } \\
\text { tamper- } \\
\text { proof and } \\
\text { give } \\
\text { authentic } \\
\text { and } \\
\text { conclusive } \\
\text { ownership } \\
\text { rights. }\end{array}$ & Yes & Yes & $\begin{array}{l}\text { to } \\
\text { combine } \\
\text { Blockchai } \\
\text { n } \\
\text { technolog } \\
\text { y with } \\
\text { artificial } \\
\text { intelligenc } \\
\text { e (AI) in } \\
\text { order to } \\
\text { make the } \\
\text { entire land } \\
\text { manageme } \\
\text { nt } \\
\text { ecosystem } \\
\text { safer, } \\
\text { faster, } \\
\text { more } \\
\text { transparen } \\
\text { t, and } \\
\text { more } \\
\text { responsive } \\
\text {. }\end{array}$ \\
\hline
\end{tabular}

Table 1. Comparative and Comprehensive Review Analysis Based on Selective Criteria

\section{CONCLUSION AND DISCUSSION}

This article began by stating that the advent of "blockchain" technology prompted conceptual and design work in a variety of fields aimed at realising the previous "smart contract" notion. The research focused on a Systemic Literature Review of contemporary research work conducted between 2015 and 2021. Its current analysis is a comparative and comprehensive review of block chain applications in numerous domains. According to current research, only a few application sectors have been covered for blockchain technology deployment, such as the health sector, insurance sector, e-voting sector, or land sector. In the future, Blockchain technology combined with smart contacts could be used in a variety of sectors that are currently untapped.

FUNDING: This study was not funded by any organization.

CONFLICT OF INTEREST: The authors declare that they have no conflicts of interest.

\section{REFERENCES}

1. Satoshi Nakamoto "Bitcoin: A Peer-to-Peer Electronic Cash System," 2008.

2. Antony Lewis "A Gentle Introduction to Ethereum," 2016.
3. Andreas M. Antonopoulos, Gavin Wood, "What is a Smart Contract?" 2018.

4. Fahim Ullah, Fadi Al-Turjman "A conceptual framework for blockchain smart contract adoption to manage real estate deals in smart cities," 2021.

5. Adarsh Kumar Rajalakshmi Krishnamurthi, Anand Nayyar, Kriti Sharma, Vinay Grover and Eklas Hossain, "A Novel Smart Healthcare Design, Simulation, and Implementation Using Healthcare 4.0 Processes," 2020.

6. Mayank Raikwar Subhra Mazumdar, Sushmita Ruj, Sourav Sen Gupta, Anupam Chattopadhyay, and Kwok-Yan Lam. "A Blockchain Framework for Insurance Processes," 2018.

7. Hoai Luan Pham, Thi Hong Tran, Yasuhiko Nakashima, "A Secure Remote Healthcare System for Hospital Using Blockchain Smart Contract," 2018.

8. Toqeer Ali, Adnan Nadeem, Ali Alzahrani, Salman Jan "A Transparent and Trusted Property Registration System on Permissioned Blockchain," 2020.

9. Olawande Daramola, Darren Thebus "Architecture-Centric Evaluation of Blockchain-Based Smart Contract E- Voting for National Elections," 2020.

10. Valentina Gatteschi, Fabrizio Lamberti, Claudio Demartini Chiara Pranteda and Víctor Santamaría, "Blockchain and Smart Contracts for Insurance: Is the Technology Mature Enough?" 2018.

11. Sujit Biswas, Kashif Sharif, Fan Li, Saraju P. Mohanty, "Blockchain for E-Healthcare Systems:Easier Said Than Done," 2020.

12. Frorik P. Hjalmarsson, Gunnlaugur K. Hreioarsson, Mohammad Hamdaqa, Gisli Hjalmtysson, "BlockchainBasedE-Voting System," 2018.

13. Tanesh Kumar, Vidhya Ramani, Ijaz Ahmad, An Braeken, Erkki Harjula, Mika Ylianttila "Blockchain Utilization in Healthcare: Key Requirements and Challenges" 2018.

14. Ioannis Karamitsos, Maria Papadaki, Nedaa Baker Al 
Barghuthi "Design of the Blockchain Smart Contract: AUse Case for Real Estate.” 2018.

15. Rohan Bennett, Todd Miller, Mark Pickering, Al-Karim Kara "Hybrid Approaches for Smart Contracts in Land Administration: Lessons from Three Blockchain Proofs-ofConcept" 2021.

16. Vinay Thakura,, M.N. Dojab, Yogesh K. Dwivedic, Tanvir Ahmadd, Ganesh Khadangae "Land records on Blockchain for implementation of Land Titling in India, ” 2015.

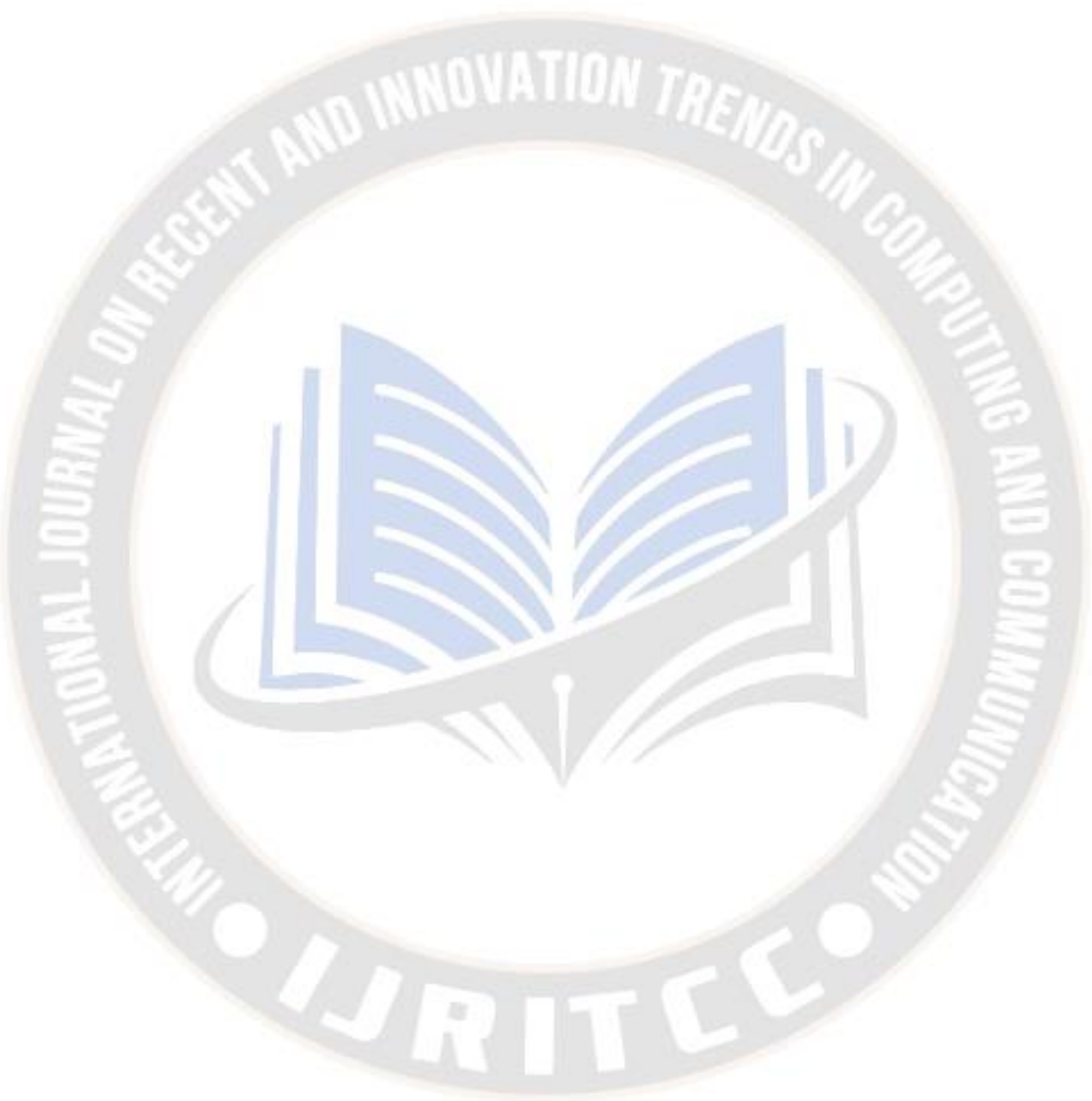

